\title{
PENGEMBANGAN MEDIA PEMBELAJARAN MATERI BILANGAN BERBASIS AUDIO VISUAL MENGGUNAKAN ADOBE FLASH PROFESIONAL CS6
}

\section{RODY SATRIAWAN, FAHRURROZI, NENY ENDRIANA, NILA HAYATI, RISTU HAIBAN HIRZI, DEDY EKA HASPANI}

\author{
Universitas Hamzanwadi \\ e-mail: rodysatriawan@hamzanwadi.ac.id
}

\section{ABSTRAK}

Penelitian ini bertujuan untuk mengembangkan media pembelajaran bilangan berbasis audio visual menggunakan adobe flash profesional CS6 untuk kelas VII MTs Mu'allimin NW Pancor yang valid, praktis, dan efektif. Penelitian ini merupakan penelitian pengembangan yang diadaptasi dari model pengembangan ADDIE. Tahapan penelitian ini ada 5 tahap, yaitu: (1) Analysis; (2) Design; (3) Development; (4) Impelementation; dan (5) Evaluation. Hasil penelitian menunjukkan bahwa media pembelajaran bilangan berbasis audio visual menggunakan adobe flash professional CS6 yang telah dikembangkan berdasarkan penilaian ahli media diperoleh sebesar 96 dengan kategori baik. Berdasarkan respon siswa terhadap kepraktisan media didapatkan persentasi penilaian sebesar 75,35\% dengan kategori praktis. Berdasarkan tes hasil belajar siswa terhadap keefektifan media yang telah dikembangkan diperoleh persentase sebesar $88,46 \%$. Berdasarkan hasil penelitian dan analisis data, dapat disimpulkan bahwa media pembelajaran bilangan berbasis audio visual menggunakan adobe flash professional CS6 layak dan dapat digunakan dalam proses pembelajaran matematika materi bilangan kelas VII MTs Mu'allimin NW Pancor.

Kata kunci: Adobe Flash Profesional CS6, ADDIE, Audio Visual, Pengembangan Media

\section{ABSTRACT}

This research aimed to develop audio visual based on learning media using adobe flash professional CS6 in material subject for students of seventh graders at MTs Mu'allimin NW Pancor that was valid, practical and effective. This research was a research and development $(R \& D)$ that was adapted from the ADDIE development model. There are 5 stages: (1) Analysis; (2) Design; (3) Development; (4) Implementation; and (5) Evaluation. The population was students of seventh graders, with a sample of students of VIIB . Data collection techniques used were using a questionnaire that was analyzed descriptively. The results showed that audio visual based on learning media using adobe flash professional CS6 which had been developed based on the assessment of media experts obtained by 96 with a very good category and material expert assessment was obtained by 42 with a good category. Based on students' responses to the practicality of the media it was found that the percentage of assessment was $75.35 \%$ with the practical category. Based on tests of student learning outcomes on the effectiveness of the media obtained a percentage of $88.46 \%$. Based on the results of data acquisition shows that audio visual based learning media using adobe flash professional CS6 was feasible and can be used in the mathematics learning process of material for students of seventh graders at MTs Mu'allimin NW Pancor.

Keywords : Adobe Flash Profesional CS6, ADDIE, Audio Visual, Media Development

\section{PENDAHULUAN}

Dalam Kurikulum 2013, pendekatan yang digunakan adalah pendekatan yang berpusat pada siswa (student centered learning). Hal ini tertuang secara jelas dalam permendikbud No. 81A tentang implementasi Kurikulum 2013 (2013). Pembelajaran berpusat pada siswa menjadi pendekatan wajib bagi pembelajaran kurikulum 2013 dimana aspek kepentingan siswa dan kemampuan siswa diutamakan. Pembelajaran berpusat pada siswa harus memberi ruang bagi siswa untuk belajar menurut ketertarikannya, kemampuan pribadinya, dan gaya belajarnya.

Pendekatan yang berpusat pada siswa merupakan pendekatan yang berfokus pada kebutuhan siswa dengan membuat mereka bertanggung jawab untuk belajar dan dengan 
mengurangi ketergantungan mereka pada siswa lain maupun guru (Spooner, E., 2015). Pembelajaran berpusat pada siswa efektif sebagai teknik mengajar guru di Sekolah (Asoodeh, M. H., Asoodeh, M. B., \& Zarepour, M, 2012). Pembelajaran yang berpusat pada siswa telah menghasilkan peningkatan nilai siswa yang lebih tinggi dibandingkan dengan pendekatan lainnya (Suresh, P., \& Rajest, S. S, 2019).

Media sebagai bagian integral pembelajaran, komponen ini perlu mendapatkan perhatian para guru. Pentingnya media dalam memfasilitasi siswa, penyajiannya disesuaikan dengan tujuan pembelajaran yang ditetapkan (Miftah, 2013). Hadirnya media dalam proses pembelajaran sangat membantu siswa lebih memahami hal yang dipelajar. Penggunaan media pembelajaran sangat berpengaruh terhadap hasil belajar siswa dalam muatan pembelajaran IPA. Selain itu siswa juga mempunyai pengalaman yang berbeda dalam proses pembelajaran menggunakan media. Hal ini juga dapat meningkatkan kemampuan siswa dalam memahami materi pelajaran dengan mudah melalui penggunaan media selama proses pembelajaran. (Wahyuningtyas, R., \& Sulasmono, B. S., 2020).

Fakta di lapaggan menunjukkan penggunaan media pembelajaran berbasis audio visual dalam kegiatan pembelajaran di MTs Mu'allimin NW Pancor masih sangat kurang. Guru mata pelajaran matematika di MTs Mu'allimin NW Pancor masih terpaku pada metode ceramah dalam penyampaian materi, praktik, dan demonstrasi, sehingga siswa masih kesulitan memahami materi pelajaran. Selain itu, proses pembelajaran masih dilakukan kurang inovatif dan kreatif. Guru masih menggunakan metode penyampaian ceramah dan media yang hanya bersumber dari buku paket matematika. Hal tersebut menyebabkan penjelasan dari guru dengan media itu saja tidak cukup untuk siswa memahami dan mempraktikkan materi, karena masih ada siswa mengalami kesulitan dalam memahami materi yang diberikan, terkadang guru harus mengulang dan menjelaskan kembali materi yang sama.

Sebagaimana kita ketahui bahwa objek-objek matematika bersifat abstrak. Hal demikian berpotensi akan memunculkan berbagai kesulitan dalam mempelajarinya, terutama bagi siswa di kelas tingkat rendah, mengingat mereka pada umumnya belum mampu berpikir secara abstrak. Fakta demikian mendorong pengalaman visual kepada siswa dalam berinteraksi dengan objek-objek matematika yang bersifat abstrak tersebut (Mashuri, 2019). Dengan demikian, untuk mendukung berjalannya pembelajaran yang memiliki kualitas yang baik dibutuhkan media pembelajaran berupa media audia visual.

Hasil penelitian yang telah dilakukan menunjukkan bahwa media audio visual memiliki pengaruh yang signifikan terhadap hasil belajar matematika (Prasetia, F, 2016; Jusmiana, A., Herianto, H., \& Awalia, R., 2020). Selain itu, media audio visual juga dapat meningkatkan motivasi belajar siswa (Bambang, L., 2015; Mutammimah, E., 2018; Pradilasari, L., Gani, A., \& Khaldun, I, 2019). Hasil penelitian lainnya juga menunjukkan bahwa media audio visual efektif meningkatkan kemampuan mengenal konsep bilangan ratusan pada anak berkesulitan belajar (Oktriani, R., 2017).

Pengembangan media pembelajaran dapat dilakukan melalui penerapan-penerapan materi dari bidang ilmu pengetahuan matematika, salah satunya pada pembuatan media pembelajaran berbasis audio visual menggunakan adobe flash proffesional CS6. Gerantabee (2012: 1) mengemukakan bahwa Adobe Flash Professional CS6 digunakan untuk membuat dan mengirimkan konten interaktif. Adobe Flash Professional CS6 merupakan lingkungan pembuatan untuk membuat konten dan iklan yang kaya dan interaktif untuk pengiriman web digital. Gerantabee (2012) menambahkan bahwa Adobe Flash Professional CS6 menyediakan lingkungan penulisan yang komprehensif untuk membuat aplikasi interaktif dan karya media. Keuntungan bekerja di flash adalah anda dapat dengan mudah memodifikasi karya seni yang diimpor menggunakan editor eksternal, dan membuat perubahan yang diterapkan pada flash.

Hasil-hasil penelitian yang relevan menunjukkan bahwa permainan mobile gametika ini dinyatakan valid dan layak digunakan terutama untuk anak usia 10-13 tahun (Swalaganata, G., 2018). Selain itu, pemanfaatan Adobe Flash Profesional CS6 dalam pembelajaran matematika berbasis Problem Based Learning dapat mengahasilkan multimedia interaktif yang dapat 
meningkatkan motivasi, minat, pemahaman konsepdan aktivitas peserta didik terhadap pembelajaran matematika (Rezeki, S., 2018). Selanjutnya, hasil penelitian lainnya juga menunjukkan bahwa media pembelajaran menggunakan Adobe flash berbasis metakognisi yang dikembangkan oleh penelitilayak digunakan dalam pembelajaran materi fungsi komposisi dan fungsi invers untuk meningkatkan motivasi belajar siswa (Ariska, M. D., Darmadi, D., \& Murtafi'ah, W., 2018).

\section{METODE PENELITIAN}

Penelitian ini menggunakan pendekatan penelitian dan pengembangan atau Research and Development (R\&D). Penelitian pengembangan media pembelajaran bilangan berbasis audio visual ini mengadopsi model pengembangan ADDIE. Mulyatiningsih (2011) menjelaskan ADDIE merupakan singkatan dari Analysis, Design, Development, Implementation, and Evaluations.

Prosedur pengembangan berdasarkan model pengembangan yang digunakan dalam penelitian ini disajikan pada bagan sebagai berikut:

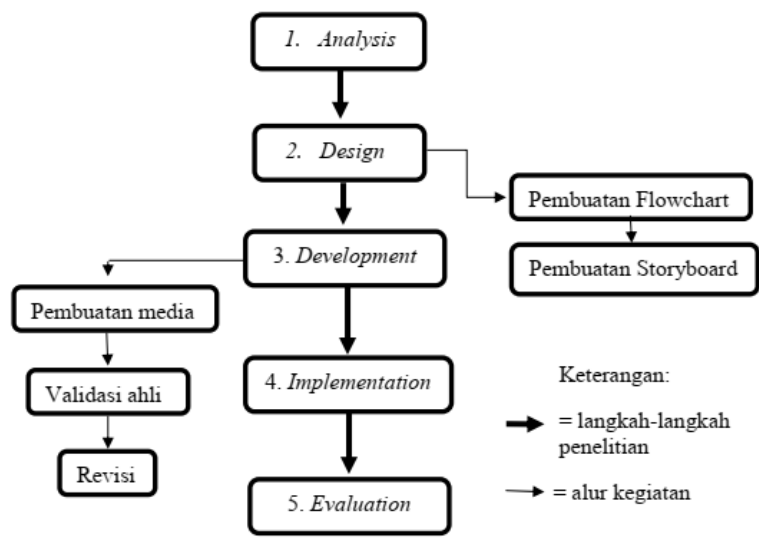

Gambar 1. Bagan Prosedur Pengembangan

Setelah produk pengembangan media pembelajaran bilangan berbasis audio visual menggunakan Adobe Flash Professional CS6 divalidasi dan dinyatakan layak oleh expert judgment (tim ahli), maka tahap selanjutnya produk diterapkan kepada penelitian. Subjek penelitian ini adalah siswa kelas VII MTs Mu'allimin NW Pancor tahun pelajaran 2019/2020 dengan jumlah total subjek uji coba ada 26 siswa.

\section{HASIL DAN PEMBAHASAN}

\section{Hasil}

\section{Tahap Analysis}

\section{a. Analisis Kurikulum}

Kurikulum yang digunakan di MTs Mu'allimin NW Pancor kelas VII adalah kurikulum 2013. Dalam kurikulim tersebut didapatkan kompetensi inti dan kompetensi dasar untuk materi bilangan, yaitu:

Kompetensi Inti:

1) Menghargai dan menghayati agama yang dianutnya.

2) Menunjukkan perilaku jujur, disiplin, tanggung jawab, peduli (toleransi, gotong royong), santun, percaya diri dalam berinteraksi secara efektif dengan lingkungan sosial dan alam dalam jangkauan pergaulan dan keberadaannya.

3) Memahami pengetahuan (faktual, konseptual, dan prosedural) berdasarkan rasa ingin tahunya tentang ilmu pengetahuan, teknologi, seni, budaya terkait fenomena dan kejadian tampak mata.

4) Mencoba, mengolah, dan menyaji dalam ranah konkret (menggunakan, mengurai, merangkai, memodifikasi, dan membuat) dan ranah abstrak (menulis, membaca, 
menghitung, menggambar, dan mengarang) sesuai dengan yang dipelajari di sekolah dan sumber lain yang sama dalam sudut pandang/teori.

Kompetensi Dasar:

1) Menjelaskan dan menentukan urutan pada bilangan bulat (positif dan negatif) dan pecahan (biasa, campuran, desimal, persen).

2) Menjelaskan dan melakukan operasi hitung bilangan bulat dan pecahan dengan memanfaatkan berbagai sifat operasi.

3) Menjelaskan dan menentukan reprentasi bilangan bulat besar sebagai bilangan berpangkat bulat positif.

4) Menyelesaikan masalah yang berkaitan dengan urutan beberapa bilangan bulat dan pecahan (biasa, campuran, desimal, persen).

5) Menyelesaikan masalah yang berkaitan dengan operasi hitung bilangan bulat dan pecahan

6) Menyelesaikan masalah yang berkaitan dengan bilangan bulat besar sebagai bilangan berpangkat bulat positif

b. Analisis Kebutuhan

Berdasarkan informasi yang didapatkan dari kepala sekolah serta pengamatan peneliti, siswa sangat tertarik dengan proses pembelajaran menggunakan teknologi, tetapi guru mata pelajaran masih kurang dalam penggunaan perangkat pembelajaran berbasis teknologi karena masih terbiasa menggunakan perangkat yang tidak berbasis teknologi. Siswa juga terbawa oleh perkembangan teknologi sehingga terbiasa mendapatkan informasi dan pengetahuan melalui perangkat teknologi informasi interaktif, seperti CD-ROM multimedia, internet dan lain sebagainya. Sehingga perlu ada solusi untuk memenuhi kebutuhan tersebut dengan mengadakan proses pembelajaran menggunakan media yang berbasis teknologi. Namun ketersediaan alat pendukung seperti lab komputer di sekolah sedang dalam masa perbaikan. Oleh karena itu, peneliti harus menyiapkan komputer atau laptop untuk menunjang proses pembelajaran.

Tahap Design

Langkah-langkah membuat floechart dan storyboard dalam mendesign produk meliputi:

1) Menyusun materi yang akan disajikan ke dalam media pembelajaran berbasis audio visual menggunakan adobe flash professional CS6 yang sudah disesuaikan dengan indikator, kompetensi dasar dan tujuan pembelajaran.

2) Membuat flowchart untuk menggambarkan alur dari setiap scene.

3) Membuat storyboard untuk menggambarkan deskripsi tiap scene.

Tahap Development

Pada tahap ini pengembangan media telah dilakukan, sehingga terdapat hasil pengembangan media pembelajaran berbasis audio visual menggunakan Adobe Flash Professional CS6 sebagai berikut:

a. Rancangan Media Pembelajaran berikut:

Tampilan scene registrasi untuk masuk media pembelajaran yang telah dibuat sebagai 


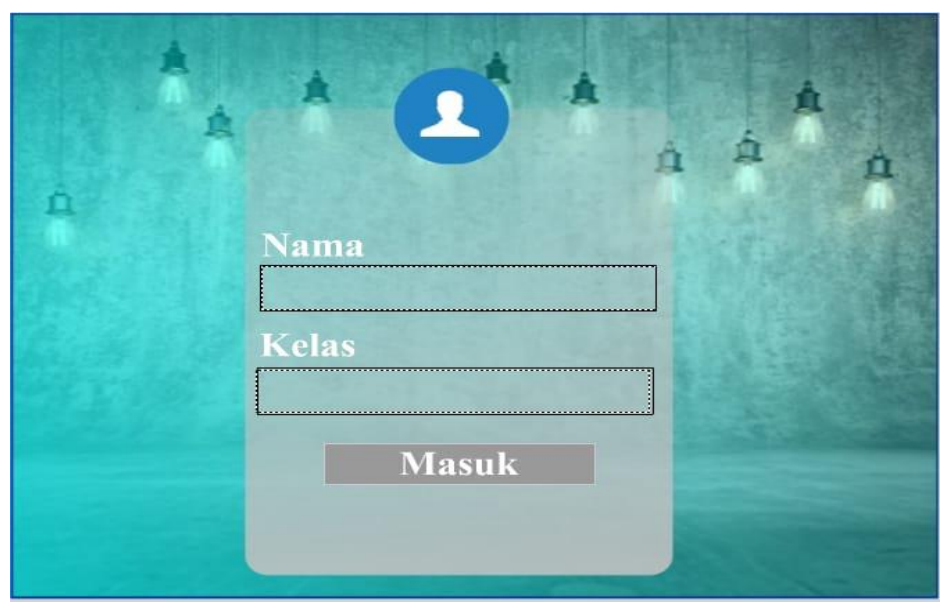

Gambar 2. Scene Registrasi Media Pembelajaran

Tampilan scene menu media pembelajaran sebagai berikut:

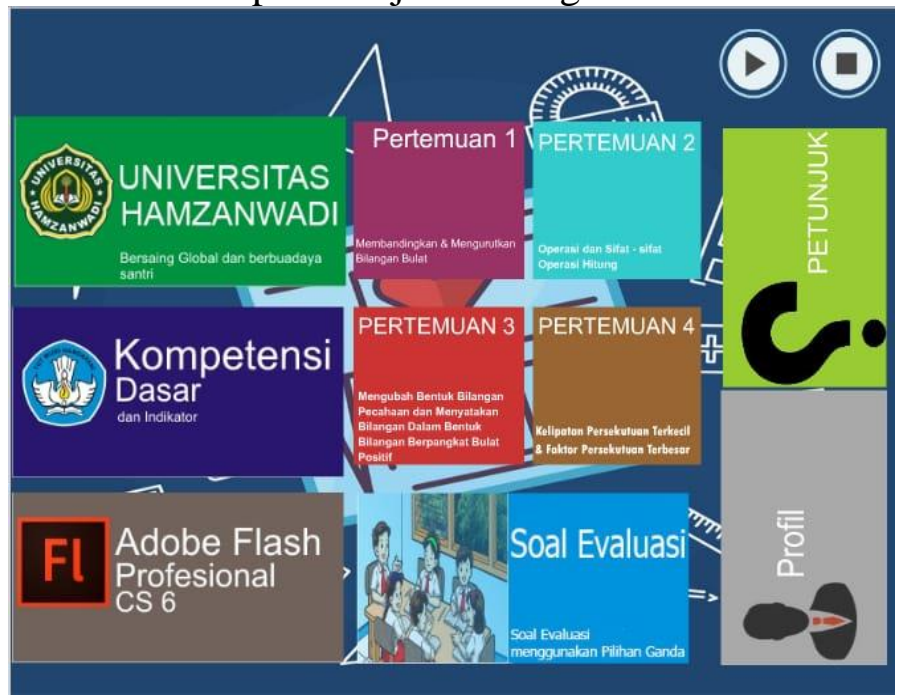

Gambar 3. Scene Menu Media Pembelajaran

Tampilan scene petunjuk penggunaan media pembelajaran sebagai berikut:

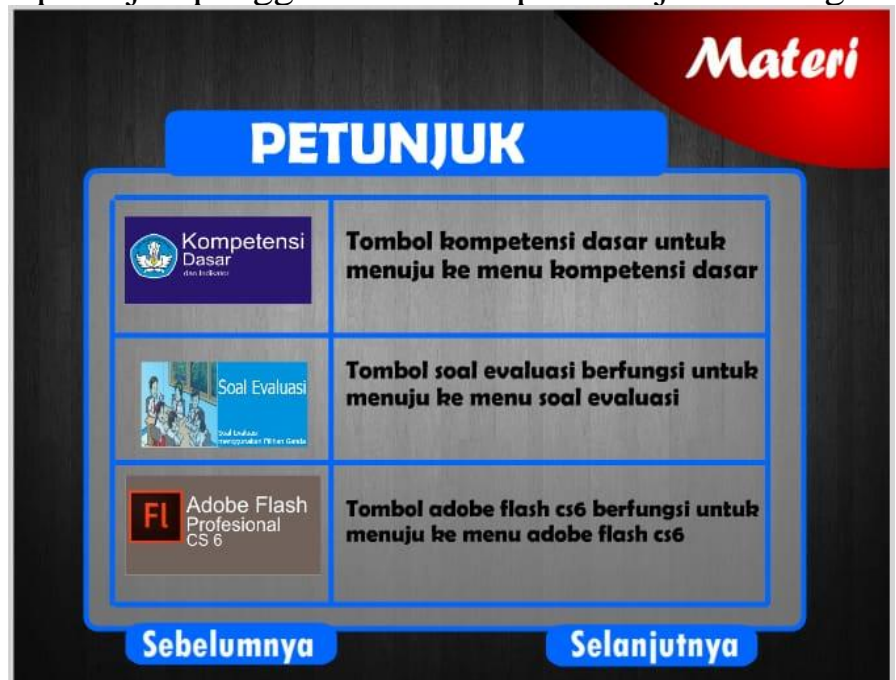

\section{Gambar 4. Scene Petunjuk Media Pembelajaran}

Tampilan scene kompetensi inti (KI), kompetensi dasar (KD), dan indikator pembelajaran sebagai berikut: 


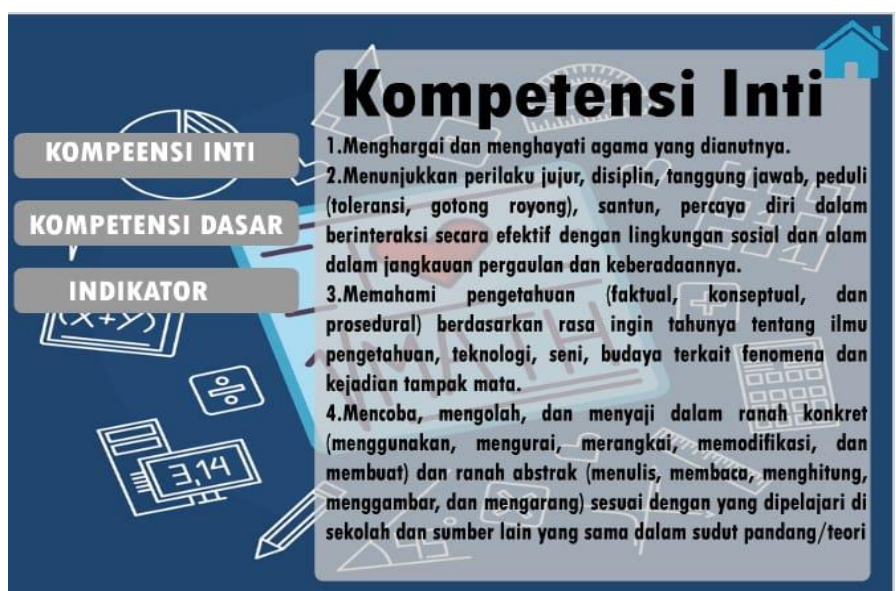

Gambar 5. Tampilan Scene Kompetensi inti (KI), kompetensi dasar (KD), dan Indikator Pembelajaran pada Media Pembelajaran

Tampilan scene untuk materi awal bilangan sebagai berikut:

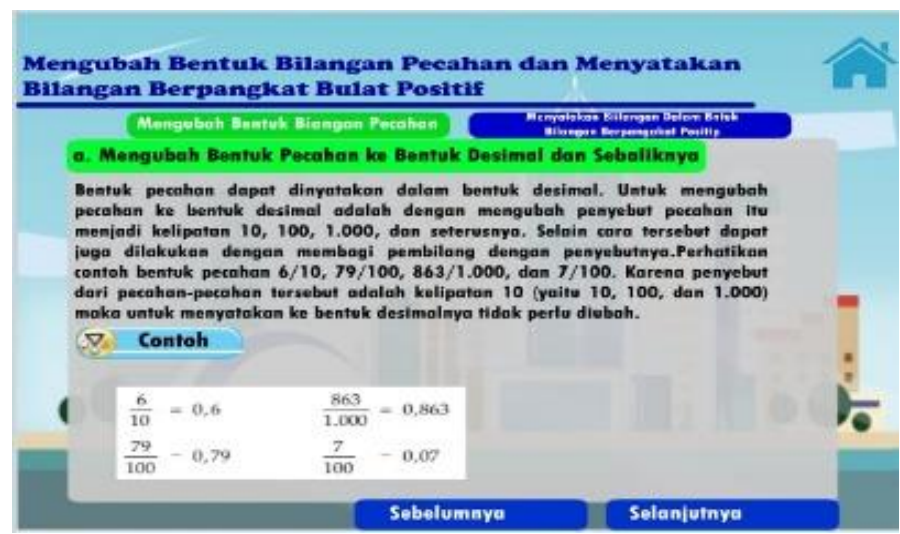

Gambar 6. Scene Materi Awal Bilangan (Halaman 1)

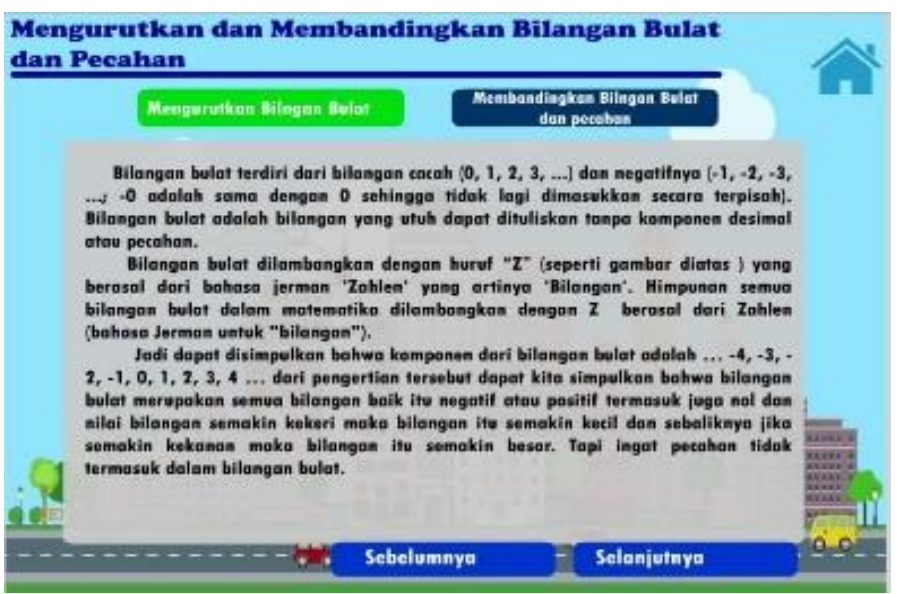

Gambar 7. Scene Materi Awal Bilangan (Halaman 2) 


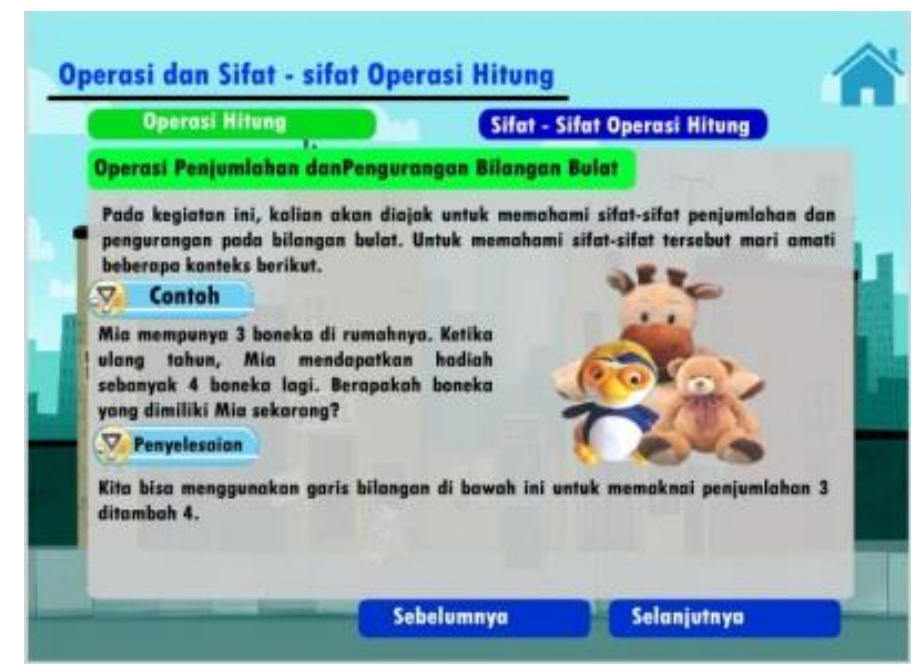

Gambar 6. Scene Materi Awal Bilangan (Halaman 3)

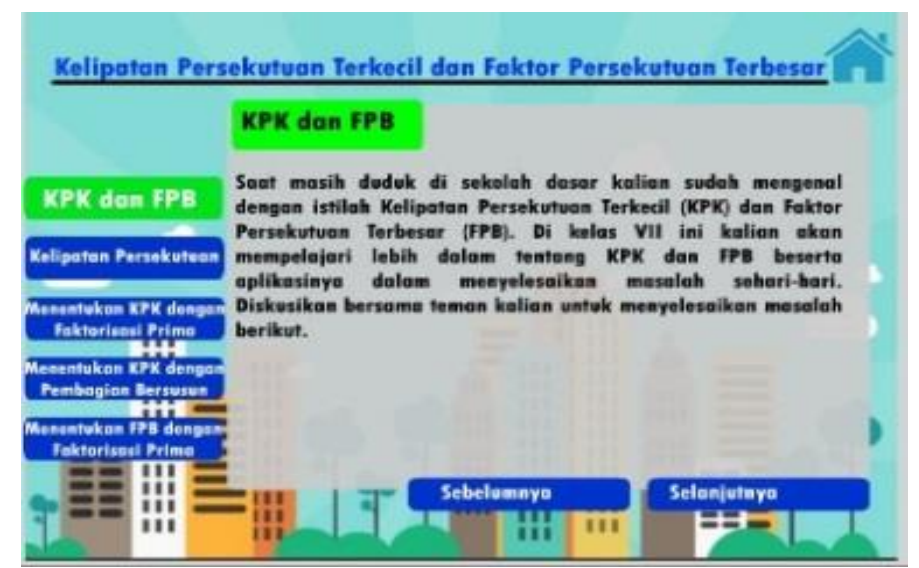

Gambar 7. Scene Materi Awal Bilangan (Halaman 4)

Tampilan scene evaluasi untuk mengukur pemahaman siswa sebagai berikut:

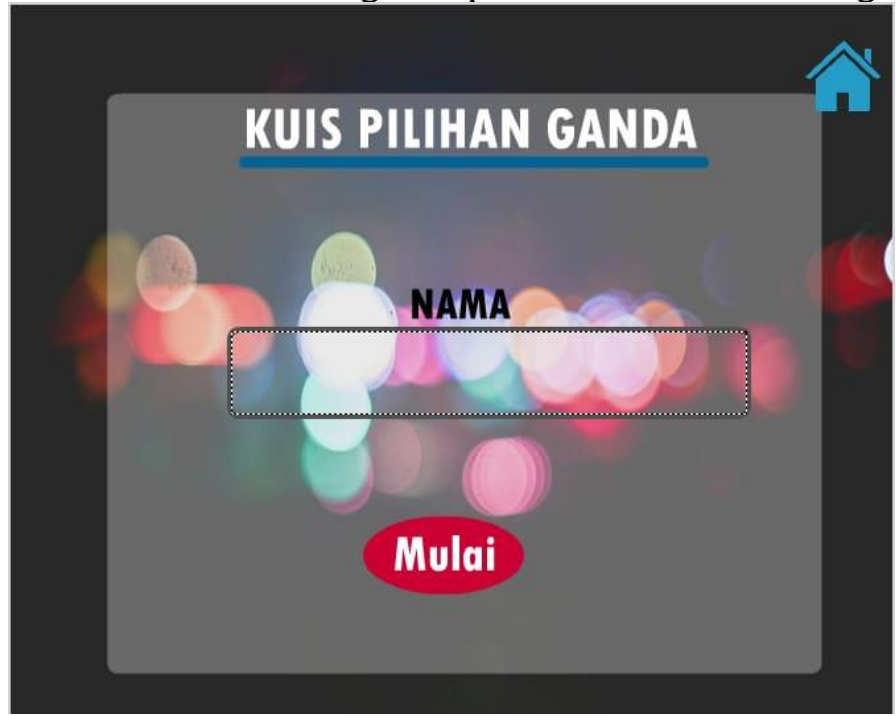

Gambar 7. Scene Evaluasi Media Pembelajaran

b. Validasi Tim Ahli

1) Data Hasil Penilaian Ahli Materi

Hasil penilaian media pembelajaran bilangan berbasis audio visual menggunakan adobe flash professional CS6 oleh ahli materi disajikan sebagai berikut: 
Tabel 1. Data Penilaian Ahli Materi dari Aspek Tujuan Pembelajaran

No Indikator Penilaian

Skor Ahli

Materi

\begin{tabular}{llcc} 
& & \multicolumn{2}{c}{ Materi } \\
\cline { 3 - 4 } & & I & II \\
\hline 1 & $\begin{array}{l}\text { Kesesuaian materi yang disajikan sesuai dengan KI, KD, } \\
\text { dan indikator }\end{array}$ & 5 & 4 \\
\hline 2 & Ketetapan dalam memilih materi yang disajikan & 4 & 4 \\
\hline 3 & Kejelasan petunjuk menggunakan media dalam belajar & 4 & 4 \\
\hline 4 & $\begin{array}{l}\text { Kemudahan materi yang dipelajari dengan menggunakan } \\
\text { media aplikasi android }\end{array}$ & 4 & 4 \\
\hline 5 & Ketetapan dalam memilih bahasa pada media & 5 & 4 \\
\hline JUMLAH SKOR AKTUAL & 22 & 20 \\
\hline RATA-RATA JUMLAH SKOR AKTUAL & \multicolumn{2}{c}{21} \\
\hline
\end{tabular}

Tabel 2. Data Penilaian Ahli Materi dari Aspek Pembelajaran

\begin{tabular}{clcc}
\hline No & \multicolumn{1}{c}{ Indikator Penilaian } & \multicolumn{2}{c}{ Skor Ahli Materi } \\
\hline 1 & Kejelasan materi yang disampaikan menggunakan media & 5 & 4 \\
\hline 2 & Sistematika penyajian materi & 4 & 3 \\
\hline 3 & Urutan materi & 4 & 4 \\
\hline 4 & Kesesuaian contoh yang disajikan & 5 & 4 \\
\hline 5 & Ketetapan gambar yang disajikan dalam media & 5 & 4 \\
\hline JUMLAH SKOR AKTUAL & 23 & 19 \\
\hline \multicolumn{2}{l}{ RATA-RATA JUMLAH SKOR AKTUAL } & 22 &
\end{tabular}

2) Data Hasil Penilaian Ahli Media

Hasil penilaian media pembelajaran berbasis audio visual menggunakan adobe flash professional CS6 oleh ahli media diasajikan sebagai berikut:

Tabel 3. Data Penilaian Ahli Media dari Kualitas Teknis

\begin{tabular}{clc} 
No & \multicolumn{1}{c}{ Indikator Penilaian } & $\begin{array}{c}\text { Skor Ahli } \\
\text { Media }\end{array}$ \\
\hline 1 & Teks pada media pembelajaran terbaca dengan jelas & 5 \\
\hline 2 & Ukuran teks pada media pembelajaran proporsional sehingga mudah dibaca & 4 \\
\hline 3 & Jenis huruf (font) yang digunakan pada media pembelajaran mudah dibaca & 4 \\
\hline 4 & Media pembelajaran mempermudah siswa dalam proses belajar & 4 \\
\hline 5 & Menu yang terdapat pada media pembelajaran mudah dijalankan & 5 \\
\hline 6 & Tampilan media pembelajaran menarik & 4 \\
\hline 7 & Animasi pada media pembelajaran tidak mengganggu konsentrasi siswa & 5 \\
\hline 8 & Pemilihan musik/sound pada media pembelajaran sudah sesuai & 4 \\
\hline & Jumlah Skor Aktual & 35 \\
\hline
\end{tabular}

Tabel 4. Data Penilaian Ahli Media dari Aspek Kualitas Desain Interface

\begin{tabular}{clc}
\hline No & \multicolumn{1}{c}{ Indikator Penilaian } & $\begin{array}{c}\text { Skor Ahli } \\
\text { Media }\end{array}$ \\
\hline 1 & Gambar yang digunakan media pembelajaran jelas & 5 \\
\hline 2 & Pemilihan warna teks dengan background pada media pembelajaran sesuai & 4 \\
\hline 3 & Penggunaan bahasa pada media pembelajaran mudah dipahami & 4 \\
\hline 4 & $\begin{array}{l}\text { Tampilan media pembelajaran mudah dipahami sehingga } \\
\text { menimbulkan kebingungan bagi siswa }\end{array}$ & 4 \\
\hline 5 & Tombol pada media pembelajaran mudah dioperasikan & \\
\hline
\end{tabular}




\begin{tabular}{clc}
\hline 6 & Tombol navigasi pada media pembelajaran dapat berfungsi dengan baik & 5 \\
\hline 7 & Tata letak gambar pada media pembelajaran konsisten & 4 \\
\hline 8 & Tata letak tombol-tombol navigasi pada media pembelajaran konsisten & 5 \\
\hline 9 & Ukuran tombol navigasi pada media pembelajaran konsisten & 5 \\
\hline 10 & Tombol navigasi pada media pembelajaran mudah dikenali & 4 \\
\hline 11 & Fungsi tombol yang ada pada media pembelajaran jelas & 5 \\
\hline 12 & $\begin{array}{l}\text { Media pembelajaran dapat digunakan untuk pembelajaran di sekolah } \\
\text { maupun dirumah secara mandiri }\end{array}$ & 4 \\
\hline 13 & $\begin{array}{l}\text { Media pembelajaran memberikan kesempatan siswa untuk latihan secara } \\
\text { teori maupun praktik. }\end{array}$ & 4 \\
\hline & $\quad$ Jumlah Skor Aktual & 57 \\
\hline
\end{tabular}

Tabel 5. Data Penilaian Ahli Media dari Aspek Konten

\begin{tabular}{ccc}
\hline No & Indikator Penilaian & $\begin{array}{c}\text { Skor Ahli } \\
\text { Media }\end{array}$ \\
\hline 1 & Latihan soal pada media pembelajaran relevan dengan materi & 4 \\
\hline & Jumlah Skor Aktual & 4
\end{tabular}

Berdasarkan tabel data penilaian ahli media dari aspek kualitas teknis, desain interface, dan konten memiliki 22 indikator penilaian. Jadi skor aktual yang diperoleh dari penialain ahli media berdasarkan aspek kualitas teknis, desain interface, dan konten adalah $35+57+4=96$.

c. Revisi Produk

Produk yang dikembangkan sudah melalui tahap penialaian ahli media, ahli materi, guru mata pelajaran dan siswa. Masing-masing memberikan masukan dan saran terhadap media yang dikembangkan, dan masukan dan saran tersebut menjadi bahan revisi peneliti untuk menyempurnakan media pembelajaran yang sedang dikembangkan, sehingga menghasilkan produk yang lebih sempurna dan bisa digunakan dalam pembelajaran.

\section{Tahap Implementation}

Media yang telah dikembangkan dan mendapat perbaikan dan dinyatakan valid oleh ahli media dan ahli materi kemudian diterapkan kepada siswa kelas VII MTs Mu'allimin NW Pancor.

a. Data Kepraktisan Media

Responden pada pengujian ini adalah siswa kelas VII MTs Mu'allimin NW Pancor sejumlah 26 responden dan data kepraktisan yang diperoleh berjumlah 15 item.

b. Data Keefektifan Media

Hasil belajar siswa yang diperoleh dengan mengerjakan tes yang berjumlah 20 butir soal pilahan ganda diberikan setelah berakhirnya proses pembelajaran.

\section{Tahap Evaluation}

Pada tahap ini, dilakuakn analisis data. Hasil analisis data yang telah dilakukan disajikan sebagai berikur:

a. Analisis Data Validitas

1) Analisis Data Hasil Validasi Ahli Materi

Rata-rata jumlah skor aktual dari ahli materi 1 dan 2 sebesar 42 berada pada interval $34,02<X \leq 42,06$ dengan kategori baik untuk diuji cobakan.

2) Analisis Data Hasil Validasi Ahli Media

Rata-rata jumlah skor aktual oleh ahli media ditinjau dari aspek kualitas teknis, desain interface, dan konten sebesar 96. Rata-rata jumlah skor aktual sebesar 96 berada pada interval $X>92,46$ dengan kategori sangat baik untuk diuji cobakan. 
a. Analisis Data Kepraktisan Media

Persentasi siswa yang aktif setelah menggunakan media pembelajaran berbasis audio visual menggunakan Adobe Flash Professional CS6 adalah 71,95\%.

b. Analisis Data Keefektifan Media

Hasil penerapan media dengan ketuntasan $88,46 \%$ dapat disimpulkan bahwa proses pembelajaran menggunakan media pembelajaran berbasis audio visual menggunakan Adobe Flash Professional CS6 pada materi bilangan dapat meningkatkan hasil belajar siswa dan dapat digunakan dalam proses pembelajaran.

\section{Pembahasan}

Pengembangan media bilangan berbasis audio visual menggunakan Adobe Flash Professional CS6 ini sudah melalui tahap-tahap pengembangan yang mengacu pada model pengembangan ADDIE. Media ini dalam proses pengembangannya menggunakan perangkat lunak Adobe Flash Professional CS6, kemudian dikemas dalam bentuk compact disk (CD). Media pembelajaran bilangan berbasis audio visual menggunakan Adobe Flash Professional CS6 pada materi bilangan ini dikatakan layak. Kelayakan suatu media pembelajaran jika memiliki kevalidan, kepraktisan dan keefektifan. Kevalidan, kepraktisan, dan keefektifan tersebut diperoleh melalui tahap-tahap penilaian para ahli dan telah diterapkan pada pembelajaran di kelas.

Secara teori, hasil pengembangan produk yang telah diperoleh ini didukung oleh ahli Adobe Flash Professional CS6 terkemuka yaitu Fred Gerantabee. Gerantabee (2021) mengemukakan bahwa kelebihan bekerja dengan menggunakan Adobe Flash Professional CS6, yaitu dalam setiap dokumen Flash Professional CS6, anda akan menemukan alat canggih yang dirancang untuk membantu anda membuat dan mendesain film maupaun bentuk yang lainnya secara efektif. Saat anda membuat grafik di stage anda akan menyadari bahwa anda mungkin ingin menggunakan kembali grafik tersebut beberapa kali sepanjang film anda. Pilihan yang lebih baik adalah menggunakan simbol: grafik, gambar, dan animasi yang dapat digunakan kembali yang disimpan di pustaka dokumen anda. Perubahan yang dibuat pada simbol asli di perpustakaan Anda memengaruhi semua contoh simbol itu di seluruh film Anda.

Gerantabee (2012) menambahkan bahwa salah satu keuntungan bekerja di flash adalah anda dapat dengan mudah memodifikasi karya seni yang diimpor menggunakan editor eksternal, dan membuat perubahan yang diterapkan pada flash. Selain mengimpor format gambar bitmap standar, flash menawarkan impor asli file .psd Photoshop. Ini berarti anda dapat mengimpor file Photoshop berlapis dan memilih lapisan mana yang akan diimpor dan bagaimana memperlakukan setiap lapisan saat ditempatkan pada flash.

Selain itu, hasil pengembangan produk yang telah diperoleh ini juga didukung oleh hasilhasil penelitian yang telah dilakukan. Pemanfaatan Adobe Flash Profesional CS6 dalam pembelajaran matematika berbasis Problem Based Learning dapat menghasilkan multimedia interaktif yang dapat meningkatkan motivasi, minat, dan pemahaman konsep dan aktivitas peserta didik terhadap pembelajaran matematika (Rezeki, S., 2018). Hasil penelitian lainnya juga menunjukkan bahwa media pembelajaran menggunakan Adobe flash berbasis metakognisi yang dikembangkan oleh peneliti layak digunakan dalam pembelajaran materi fungsi komposisi dan fungsi invers untuk meningkatkan motivasi belajar siswa (Ariska, M. D., Darmadi, D., \& Murtafi'ah, W., 2018).

Adapun kelebihan dari media pembelajaran ini adalah tampilan yang lebih inovatif dan berbeda, tampilan materi yang menarik dan siswa bisa belajar secara mandiri, memiliki tomboltombol navigasi yang interaktif dan konsisten, serta adanya karakteristik program yang memuat ukuran file yang sangat kecil dan menguntungkan jika di-upload ke internet. Sedangkan kekurangan dari media pembelajaran ini adalah terbatasnya poko pembahasan yang disampaikan, bentuk file ekstensi (exe) dan CD interaktif yang hanya dijalankan pada komputer, dan hanya dapat diterapkan pada sekolah yang memiliki fasilitas pendukung seperti lab komputer, laptop atau komputer. 
Media pembelajaran ini bersifat media pembelajaran yang interaktif yang didesain untuk pembelajaran individual, namun guru juga harus tetap memberikan penjelasanpenjelasan untuk membantu pemahaman siswa. Oleh karena itu, guru harus tetap memberikan penjelasan-penjelasan untuk mempercepat pemahaman siswa sehingga siswa dapat meningkatkan prestasi belajarnya pada mata pelajaran matematika.

\section{KESIMPULAN}

Pengembangan media pembelajaran bilangan berbasis audio visual menggunakan adobe flash profesional cs6 dengan menggunakan model pengembangan ADDIE telah memperoleh kriteria layak digunakan karena telah sesuai dengan kriteria valid, praktis, dan efktif. Hasil validasi ahli materi menyatakan jumlah skor aktual sebesar 42 berada pada interval 34,02< $X \leq 42,06$ dan termasuk dalam kategori valid. Selain itu, hasil validasi ahli media menyatakan jumlah skor aktual sebesar 96 berada pada interval $X>92,46$ dan termasuk dalam kategori sangat valid untuk digunakan. Media pembelajaran bilangan ini dinyatakan praktis pula berdasarkan hasil analisis keterlaksanaan pembelajaran yaitu sebesar $71,95 \%$ yang termasuk ke dalam kateogori praktis. Hasil tes hasil belajar siswa menyatakan ketuntasan belajar sebesar $88,46 \%$, yang menunjukkan bahwa proses pembelajaran dengan menggunakan media pembelajaran bilangan ini efektif meningkatkan hasul belajar siswa.

\section{DAFTAR PUSTAKA}

Ariska, M. D., Darmadi, D., \& Murtafi'ah, W. (2018). Pengembangan media pembelajaran menggnakan Adobe Flash berbasis metakognisi untuk meningkatkan Motivasi Belajar matematika. Edumatica: Jurnal Pendidikan Matematika, 8(01), 83-97. https://doi.org/10.22437/edumatica.v8i01.4622.

Asoodeh, M. H., Asoodeh, M. B., \& Zarepour, M. (2012). The impact of student-centered learning on academic achievement and social skills. Procedia-Social and Behavioral Sciences, 46, 560-564.

Bambang, L. (2015). Penerapan pembelajaran media Audio-Visual untuk meningkatkan Motivasi dan Hasil Belajar pada mata pelajaran Biologi Di Kelas VIII A SMP GKST Imanuel http://jurnal.untad.ac.id/jurnal/index.php/JSTT/article/view/6925/5564.

Gerantabee, F., \& Team, A. C. (2012). Adobe flash professional CS6 digital classroom. John Wiley \& Sons.

Hanafri, M. I., Ramdhan, S., \& Nisa, K. (2017). Aplikasi pembelajaran interaktif pengenalan profesi berbasis multimedia menggunakan Adobe Flash CS6. Jurnal Sisfotek Global, 7(2).

https://stmikglobal.ac.id/journal/index.php/sisfotek/article/view/148/pdf.

Jusmiana, A., Herianto, H., \& Awalia, R. (2020). Pengaruh Penggunaan Media Audio Visual Terhadap Hasil Belajar Matematika Siswa Smp Di Era Pandemi Covid-19. Pedagogy: Jurnal Pendidikan Matematika, 5(2), 1-11. https://doi.org/10.30605/pedagogy.v5i2.400.

Mashuri, S. (2019). Media pembelajaran matematika. Deepublish.

Miftah, M. (2013). Fungsi, dan peran media pembelajaran sebagai upaya peningkatan $\begin{array}{llll}\text { kemampuan } & \text { belajar } \quad \text { siswa. Jurnal }\end{array}$ https://core.ac.uk/download/pdf/235523078.pdf.

Mulyatiningsih, E. (2011). Evaluasi suatu program. Jakarta: Bumi Aksara.

Mutammimah, E. (2018). Peningkatan Motivasi Belajar melalui Bimbingan Kelompok dengan Media Audiovisual pada siswa kelas X MAN 1 Kudus. KONSELING EDUKASI" Journal of Guidance Counseling", 2(1). https://journal.iainkudus.ac.id/index.php/Konseling_Edukasi/article/view/3932/pdf.

Nair, P. (2019). Blueprint for tomorrow: Redesigning schools for student-centered learning. Harvard Education Press. 
Netriwati, M. S. L., \& Lena, M. S. (2018). Media pembelajaran matematika. Bandar Lampung: Permata Net.

Oktiani, R. (2017). The effectivenes of Audio Visual Media to Increase the Ability of the Student with Learning Dificulties to Recognize the Concept of Hundreds (A Single Subject Research Conducted in Grade III of SDN 05 Kapalo Koto Pauh Padang). Jurnal Penelitian Pendidikan Khusus, 5(2). https://doi.org/10.24036/jupe76690.64.

Pradilasari, L., Gani, A., \& Khaldun, I. (2019). Pengembangan media pembelajaran berbasis Audio Visual pada materi koloid untuk meningkatkan Motivasi dan Hasil Belajar siswa SMA. Jurnal Pendidikan Sains Indonesia (Indonesian Journal of Science Education), 7(1), 9-15. http://www.jurnal.unsyiah.ac.id/JPSI/article/view/13293/10546.

Prasetia, F. (2016). Pengaruh media Audio Visual terhadap Hasil Belajar matematika. JKPM (Jurnal Kajian Pendidikan Matematika), 1(2), 257-266. https://journal.lppmunindra.ac.id/index.php/jkpm/article/view/1193/1078.

Rezeki, S. (2018). Pemanfaatan adobe flash CS6 berbasis problem based learning pada materi fungsi komposisi dan fungsi invers. Jurnal Pendidikan Tambusai, 2(2), 856-864. https://doi.org/10.31004/jptam.v2i4.33.

Sina, I., Farlina, E., Sukandar, S., \& Kariadinata, R. (2019). Pengaruh Multimedia Interaktif dalam Pembelajaran Matematika Terhadap Kemampuan Komunikasi Matematis Siswa. Suska Journal of Mathematics Education, 5(1), 57-67. http://ejournal.uinsuska.ac.id/index.php/SJME/article/view/5081/4255.

Spooner, E. (2015). Interactive student centered learning: A cooperative approach to learning . Rowman \& Littlefield.

Suresh, P., \& Rajest, S. S. (2019). An analysis of psychological aspects in student-centered learning activities and different methods. Journal of International Pharmaceutical Research, 46(1), 165-172.

Swalaganata, G. (2018). Pengembangan Media Pembelajaran Game Aritmatika (GAMETIKA) Menggunakan Adobe Flash CS6. Jurnal Tadris Matematika, 1(1), 1-65.

Toha, A. F. M., \& Khasanah, F. N. (2020). Media Pembelajaran Interaktif Untuk Mata Pelajaran Matematika. Jurnal Kajian Ilmiah, 20(2), 145-156. https://doi.org/10.31599/jki.v20i2.120.

Wahyuningtyas, R., \& Sulasmono, B. S. (2020). Pentingnya Media dalam Pembelajaran Guna Meningkatkan Hasil Belajar di Sekolah Dasar. EDUKATIF: JURNAL ILMU PENDIDIKAN, 2(1), https://edukatif.org/index.php/edukatif/article/view/77/pdf. 